\title{
Article
}

\section{Glucose-6-Phosphate Dehydrogenase (G6PD) Status in Neonatal Jaundice and Its Relationship with Severity of Hyperbilirubinemia}

\author{
Akhter $\mathbf{N}^{1}$, Begum $\mathbf{N}^{2}$, Ferdousi $\mathrm{S}^{3}$, Khan WA $\mathrm{W}^{4}$
}

\begin{abstract}
Background: G6PD deficiency is one of the common inherited enzymatic disorder associated with high incidence of severe neonatal hyperbilirubinemia. Objectives: To observe G6PD status in male, term neonates with jaundice and its correlation with serum level of bilirubin. Methods: This cross sectional study was conducted on 90 male, term neonates with jaundice, age ranged from 3 to 12 days (Group B) in the Department of Physiology, Bangabandhu Sheikh Mujib Medical University (BSMMU) between July 2007 to June 2008. On the basis of total serum bilirubin (TSB) level, study group was further divided into $\mathrm{B}_{1}(\mathrm{TSB}<15 \mathrm{mg} / \mathrm{dl}), \mathrm{B}_{2}(\mathrm{TSB} 15-20 \mathrm{mg} / \mathrm{dl})$ and $\mathrm{B}_{3}(\mathrm{TSB}>20 \mathrm{mg} / \mathrm{dl})$. For comparison age and sex matched 30 apparently healthy neonates (Group A) were also included in the study. Erythrocyte G6PD level was measured by Spectrophotometric method by using kit of Randox. Serum bilirubin level was measured by standard laboratory technique. For statistical analysis ANOVA, independent sample "t” test and Pearson's correlation coefficient test were performed as applicable by using SPSS windows version-12. Results: In this study, erythrocyte G6PD levels were significantly lower in moderate $(p<0.01)$ and severe $(p<0.001)$ hyperbilirubinemic group in comparison to that of control group . However, this enzyme level was lower in mild group compared to that of control but the difference was statistically non significant. Again, this enzyme levels were significantly lower in moderate $(\mathrm{p}<0.05)$ and severe $(\mathrm{p}<0.01)$ group than that of mild group and also between severe and moderate hyperbilirubinemic group $(\mathrm{p}<0.05)$. In this study, G6PD enzyme deficient were found in $1(3.33 \%)$ and $6(20 \%)$ subjects of group $B_{2}$ and $B_{3}$ respectively. Though, percentage of the subjects with enzyme deficiency were higher in severe group $\left(\mathrm{B}_{3}\right)$ compared to that of moderate group $\left(B_{2}\right)$ but the difference was statistically not significant. However, no enzyme deficient patient were found in control group $(A)$ and mild hyperbilirubinemic group $\left(B_{1}\right)$. Serum bilirubin level showed significant $(\mathrm{p}<0.05)$ positive $(\mathrm{r}=+.429)$ correlation with erythrocyte $\mathrm{G} 6 \mathrm{PD}$ level in control group (A). On the other hand, this level was negatively correlated with G6PD enzyme in groups $B_{1}(r=-.127), B_{2}$ $(r=-.120)$ and $B_{3}(r=-.671)$ but significant negative correlation in group $B_{3}(p<0.01)$. Conclusion: The results of the study revealed that severity of hyperbilirubinemia depends on degree of G6PD deficiency. Therefore, early detection of this enzymopathy and close surveillance of the affected neonates may be important in reducing the complications of severe hyperbilirubinemia.
\end{abstract}

Key words: Glucose-6-PD, Hyperbilirubinemia, Neonates

J Bangladesh Soc Physiol. 2009 Dec;4(2): 71-76

For author affiliations, see end of text.

http//www.banglajol.info/index.php/JBSP

\section{Introduction}

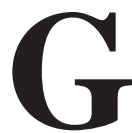

lucose-6-phosphate dehydrogenase (G6PD) is an enzyme that catalyses the first step of hexose monophosphate shunt. This enzyme provides pentoses for nucleic acid synthesis and generates NADPH.
In erythrocyte, NADPH is used to form reduced glutathione in a reaction catalyzed by glutathione reductase. G6PD helps to protect RBC from oxidative stress $^{1}$. Though most of the G6PD deficient subjects show no symptoms but they are vulnerable to develop neonatal jaundice \&

J Bangladesh Soc Physiol. 2009 Dec;4(2): 71-76 
hemolysis following intake of certain food or drugs $^{2}$. Glucose-6-phosphate dehydrogenase deficiency is a genetically determined X-linked disorder, primarily affects male. The prevalence of G6PD enzyme deficiency is high in Africa, the South East Asia, the Mediterranean the Middle East and also in population of the Indian subcontinent $^{3,4}$. In the last two decades, numerous studies have demonstrated that G6PD deficiency is a potential cause of neonatal jaundice. They also reported that significantly higher serum bilirubin level is a usual finding in neonates with G6PD deficiency ${ }^{5,6}$. Incidence of neonatal jaundice is significantly higher in G6PD deficiency in comparison to that of non deficient neonates ${ }^{7}$. Though, a few study was done to observe G6PD status in adult ${ }^{8}$ but no study has yet been reported on the contribution of G6PD deficiency in neonatal jaundice in our country. In addition, there is lack of adequate information regarding G6PD deficient hyperbilirubinemic neonates as well as G6PD status in healthy neonates in Bangladesh.

Therefore, the present study was carried out to observe the G6PD status in different groups of jaundiced neonates in order to find out its relationship with severity of hyperbilirubinemia.

\section{Methods}

The present cross sectional study was carried out in the Department of Physiology, BSMMU, Dhaka between July 2007 to June 2008 and the protocol was approved by the Ethical Committee of Bangladesh Institute of Child Health, Dhaka Shishu Hospital, Dhaka. A total number of 120 male, term, neonates, within age range of 3-12 days with and without jaundice were included in this study. Thirty apparently healthy neonates without jaundice was considered as control (group A) and 90 neonates with jaundice were included as study group (group B). On the basis of total serum bilirubin level (TSB), study group was further divided into three subgroups. Thirty neonates with TSB $<15 \mathrm{mg} / \mathrm{dl}$ were included in group $\mathrm{B}_{1}$, 30 neonates with TSB from 15 to $20 \mathrm{mg} /$

J Bangladesh Soc Physiol. 2009 Dec;4(2): 71-76 $\mathrm{dl}$ were included in group $\mathrm{B}_{2}$ and 30 neonates with TSB $>20 \mathrm{mg} / \mathrm{dl}$ were included in group $B_{3}$. Neonates less than 3 days \& more than 12 days, female, preterm, Rh incompatibility, presence of sepsis and with cephalohematoma were excluded from the study. Control subjects were selected from the Outpatient Department and study groups were selected from Inpatient Department of Dhaka Shishu Hospital, Dhaka. After selection of the subjects, aims, objectives and detail procedure of the study and the benefit of the study were explained to the parents or legal guardians by the investigator herself. The legal guardians/ parents were encouraged for voluntary participation \& they have allowed freedom to withdraw from the study even after participation whenever they feel like. If the parents or legal guardians agreed, then the neonates were enrolled to this study. Then written informed consents were taken from parents or legal guardians in a prescribed form. The cases of jaundice were diagnosed by clinical examination and was confirmed by higher total serum bilirubin level corresponding to their gestational age \& body weight. Legal guardians/parents were interviewed for detail about gestational, delivery, medical and family history. Thorough physical examinations of all the neonates were done on the $1^{\text {st }}$ day of their visit/admission into the hospital. All informations were recorded in a prefixed questionnaire. Neonates of Control group were advised to come to the next day into the hospital for biochemical and hematological examinations. Then on the $2^{\text {nd }}$ day of their visit/ admission $1.5 \mathrm{ml}$ of venous blood was collected (from both groups) for estimation of erythrocyte G6PD level, serum bilirubin. Erythrocyte G6PD level was estimated by Spectrophotometric method by using kit of $\operatorname{Randox}^{9}$ in the hematological laboratory of the Department of Physiology, BSMMU. Serum bilirubin was measured for grouping of the subject and it was done by Modified Jendrassik/Grof method ${ }^{10}$ in the biochemical laboratory of Dhaka Shishu Hospital. For statistical analysis, ANOVA, 


\section{Article}

G6PD Status in Neonatal Jaundice

Independent sample "t" test, Chi-Square test and Pearson's correlation coefficient test were performed as applicable by using SPSS windows version-12.

\section{Results}

The mean $( \pm \mathrm{SD})$ age of the subjects were $7.43 \pm$ $2.42,7.33 \pm 2.04,7.40 \pm 2.06$ and $7.30 \pm 2.00$ days and weight were $2.39 \pm 0.41,2.34 \pm 0.49,2.36 \pm$ 0.44 and $2.34 \pm 0.45 \mathrm{~kg}$ in group $\mathrm{A}, \mathrm{B}_{1}, \mathrm{~B}_{2}$ and $\mathrm{B}_{3}$ respectively. All the values were almost similar and no statistically significant differences were observed among the groups. Therefore, all the groups were matched for age and weight (Data are not shown).

The mean $( \pm S D)$ total serum bilirubin level of the subjects are presented in Figure 1.Mean erythrocyte G6PD levels were lower in groups $\mathrm{B}_{1}$, $\mathrm{B}_{2}$ and $\mathrm{B}_{3}$ in comparison to that of group $\mathrm{A}$ and the differences of these values among all these groups were statistically significant $(p<0.001)$.

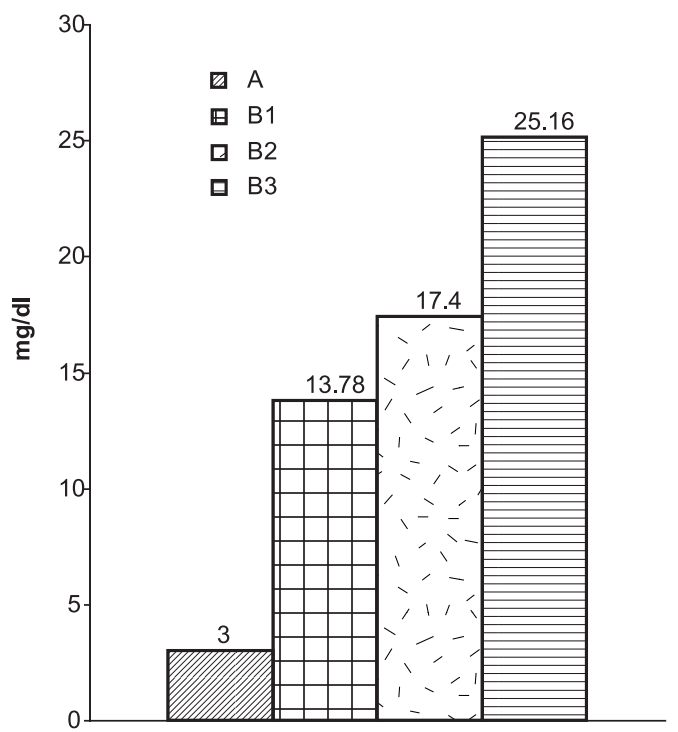

Figure 1: Mean serum bilirubin level in different groups of neonates $(n=120)$.

Group A = Apparently healthy neonates(control $<5 \mathrm{mg} / \mathrm{dl})$.

Group $B_{1}=$ Total serum bilirubin level $<15 \mathrm{mg} / \mathrm{dl}$.

Group $B_{2}=$ Total serum bilirubin level $15-20 \mathrm{mg} / \mathrm{dl}$. Group $B_{3}=$ Total serum bilirubin level $>20 \mathrm{mg} / \mathrm{dl}$.
Again, significantly lower level of this enzyme was observed in group $A$ than those of $B_{2}$ $(p<0.01)$ and $B_{3}(p<0.001)$. But though this value was lower in group $B_{1}$ in comparison to that of group A but it was not statistically significant. On the other hand, when this enzyme level was compared between the study groups, statistically significant differences were found between groups $B_{1}$ vs $B_{2}, B_{2}$ vs $B_{3}(p<0.05)$ and between $\mathrm{B}_{1}$ vs $_{3}(\mathrm{p}<0.01)$ (Table I).

Table I: Erythrocyte G6PD level in different groups of neonates $(n=120)$.

\begin{tabular}{|c|c|c|}
\hline Groups & $\mathrm{N}$ & $\mathrm{mU} / 10^{9} \mathrm{RBC}$ \\
\hline $\mathrm{A}$ & 30 & $\begin{array}{l}290.20 \pm 30.04 \\
(251-351)\end{array}$ \\
\hline $\mathrm{B}_{1}$ & 30 & $\begin{array}{l}280.90 \pm 29.01 \\
(245-344)\end{array}$ \\
\hline$B_{2}$ & 30 & $\begin{array}{l}263.77 \pm 30.64 \\
(137-311)\end{array}$ \\
\hline $\mathrm{B}_{3}$ & 30 & $\begin{array}{l}232.77 \pm 77.58 \\
(49-304)\end{array}$ \\
\hline \multicolumn{3}{|c|}{ Statistical analysis: } \\
\hline \multicolumn{2}{|l|}{ Groups } & $\mathrm{p}$ value \\
\hline \multicolumn{2}{|c|}{ A vs $B_{1}$ vs $B_{2}$ vs $B_{3}$} & $0.000 * * *$ \\
\hline \multicolumn{2}{|c|}{$A$ vs $B_{1}$} & $0.228^{n s}$ \\
\hline \multicolumn{2}{|c|}{$A$ vs $B_{2}$} & $0.001^{* *}$ \\
\hline \multicolumn{2}{|c|}{$A$ vs $B_{3}$} & $0.000 * * *$ \\
\hline \multicolumn{2}{|c|}{$\mathrm{B}_{1}$ vs $\mathrm{B}_{2}$} & $0.030 *$ \\
\hline \multicolumn{2}{|c|}{$\mathrm{B}_{1}$ vs $\mathrm{B}_{3}$} & $0.002 * *$ \\
\hline \multicolumn{2}{|c|}{$\mathrm{B}_{2}$ vs $\mathrm{B}_{3}$} & $0.046^{*}$ \\
\hline
\end{tabular}

Data were expressed as Mean \pm SD. For statistical analysis, one-way ANOVA was performed for comparison among the groups and independent sample t- test was done for comparison between the groups. Figures in parentheses indicate ranges.

Group A = Apparently healthy neonates(control $<5 \mathrm{mg} / \mathrm{dl}$ ). Group $B_{1}=$ Total serum bilirubin level $<15 \mathrm{mg} / \mathrm{dl}$.

Group $B_{2}=$ Total serum bilirubin level $15-20 \mathrm{mg} / \mathrm{dl}$. Group $B_{3}=$ Total serum bilirubin level $>20 \mathrm{mg} / \mathrm{dl}$.

$$
\begin{aligned}
& * * *=\mathrm{p}<0.001 . \quad \mathrm{ns}=\text { Not significant. } \\
& * *=\mathrm{p}<0.01 . \quad \mathrm{n}=\text { Number of subjects }
\end{aligned}
$$$$
*=\mathrm{p}<0.05
$$

J Bangladesh Soc Physiol. 2009 Dec;4(2): 71-76 
In this study, deficiency of G6PD enzyme was found in 1(3.33\%) and 6(20\%) subjects of group $B_{2}$ and $B_{3}$ respectively. Though, the percentage of the subjects with enzyme deficiency were higher in severe hyperbilirubinemic group $\left(\mathrm{B}_{3}\right)$ compared to that of moderate hyperbilirubinemic group ( $\mathrm{B}_{2}$ ) but the difference was statistically no significant. However, no enzyme deficient subjects were found in control group (A) and mild hyperbilirubinemic group $\left(\mathrm{B}_{1}\right)$ (Figure 2 ).

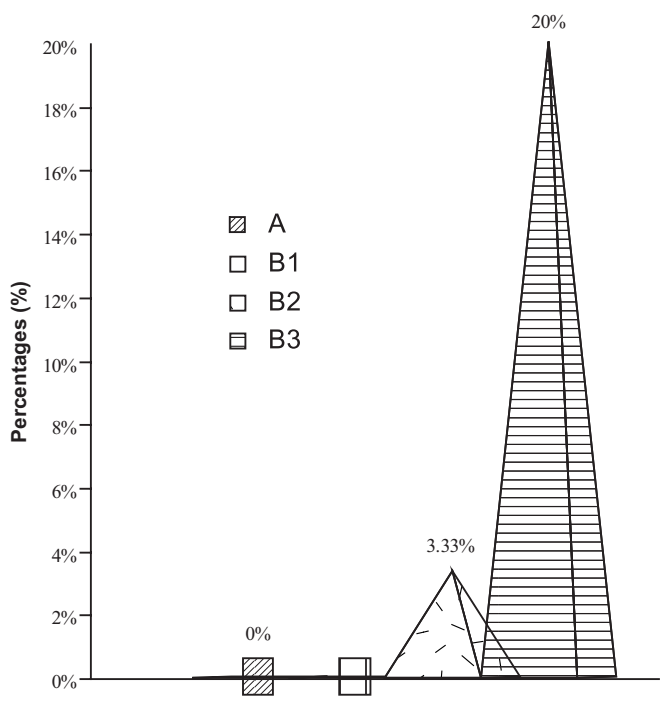

Figure 2: Distribution of the subjects by lower erythrocyte G6PD level ( $n=120)$.

Group A = Apparently healthy neonates(control $<5 \mathrm{mg} / \mathrm{dl}$ ).

Group $B_{1}=$ Total serum bilirubin level $<15 \mathrm{mg} / \mathrm{dl}$. Group $B_{2}=$ Total serum bilirubin level 15-20mg/dl. Group $B_{3}=$ Total serum bilirubin level $>20 \mathrm{mg} / \mathrm{dl}$

Correlations of serum bilirubin with erythrocyte G6PD levels are presented in figure 3. Serum bilirubin level showed significant positive $(r=+.429, \mathrm{p}<0.05)$ correlation with erythrocyte G6PD level in control group (A). On the other hand, serum bilirubin level was negatively correlated with G6PD enzyme in groups $\mathrm{B}_{1}(\mathrm{r}=-.127), \mathrm{B}_{2}(\mathrm{r}=-.120)$ and $\mathrm{B}_{3}(\mathrm{r}=$ .671) which was statistically significant only in group $\mathrm{B}_{3}(\mathrm{p}<0.01)$.

J Bangladesh Soc Physiol. 2009 Dec;4(2): 71-76

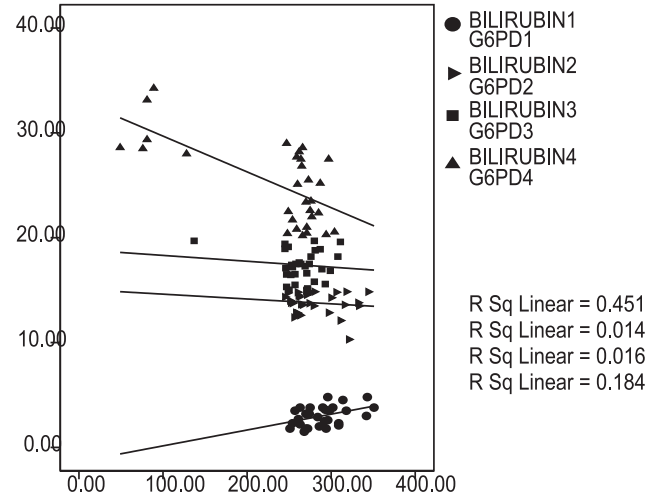

Figure 3: Correlations of serum bilirubin level with erythrocyte G6PD level in different groups of neonates $(n=120)$.

\section{Discussion}

The present study was undertaken to observe the erythrocyte G6PD status in male term neonates with jaundice and also relationship of this enzyme level with serum bilirubin level. Depending on the total serum bilirubin level study group was further divided into 3 subgroups. All these parameters were also studied in age and sex matched apparently healthy neonates without jaundice for control.

In this study, erythrocyte G6PD level was significantly lower in moderate and also in severe hyperbilirubinemic neonates in comparison to that of control. Whereas, no statistically significant difference of this enzyme level was observed between mild hyperbilirubinemic neonates and control group. Almost similar findings were reported by investigators from different countries ${ }^{5,6,9}$. However, no published data are available to compare these findings in our country.

Again, this enzyme level was significantly lower in neonates with moderate and in severe hyperbilirubinemia than that of neonates with mild hyperbilirubinemia. Erythrocyte G6PD level was significantly lower in severe hyperbilirubinemic neonates when it was compared with moderate hyperbilirubinemic 


\section{Article}

G6PD Status in Neonatal Jaundice

neonates. This findings are consistent with those of others ${ }^{10,11,12}$. Though, majority of G6PD deficient neonates were in severe hyperbilirubinemic group than that of moderate hyperbilirubinemic groups but no statistically significant differences was observed between them.

Serum bilirubin level showed significant positive correlation with erythrocyte G6PD level in control group (A) and was negatively correlated with G6PD enzyme in mild, moderate and severe hyperbilirubinemic group but it was statistically significant only in severe hyperbilirubinemic group.

It is well recognized that in G6PD deficiency, early destruction of RBC under oxidative stress causes release of hemoglobin, which subsequently metabolized and form bilirubin that leads to the development of hyperbilirubinemia in this group of neonates $3,4,10,13$.

Some researchers suggested that the deficiency of G6PD in the liver cells lead to decreased bilirubin conjugation due to its enzyme defect and this may be a major factor related to development of the hyperbilirubinemia in this group of neonates ${ }^{14}$.

Investigators from different countries showed that additional genetic factor might exacerbate hyperbilirubinemia in G6PD deficient neonates. The genetic basis for the condition has been identified as a polymorphism in the promoter for the gene which leads to reduced enzyme activity and subsequently caused decreased bilirubin conjugation ${ }^{4,11}$

Some investigators suggested that rate limiting enzyme in the production of bilirubin was increased in G6PD enzyme deficiency which subsequently aggravate the bilirubin level. ${ }^{6,11}$, though it was not possible to measure this value in the subjects of the present series.

In this study, membrane integrity defect is most likely to be the cause of excess hemolysis which is evident from the fact that maximum number of the G6PD enzyme deficient neonates fall in severe hyperbilirubinemic group. This is further supported by negative correlation of erythrocyte G6PD level with serum levels of bilirubin.

\section{Conclusion}

From the results of this study, it can be concluded that G6PD deficiency may be one of the cause of severe hyperbilirubinemia in neonates. Therefore, early detection and close surveillance for this enzyme deficiency may reduce the complications. This emphasizes the necessity of routine neonatal screening for G6PD deficiency.

Acknowledgment: The authors of this article acknowledge Dhaka Shishu Hospital for giving permission for sample collection and laboratory facility.

\section{Author Affiliations}

1. *Nilufa Akhter. Assistant Professor, Department of Physiology, Bangladesh Institute of Child Health, Dhaka Shishu Hospital, Dhaka, Bangladesh. Email:hasanimam61@yahoo.com

2. Noorzahan Begum, Professor, Department of Physiology, BSMMU, Shahbag, Dhaka, Bangladesh.

3. Sultana Ferdousi, Assistant Professor, Department of Physiology, BSMMU, Shahbag, Dhaka, Bangladesh.

4. Waqar Ahmed Khan, Professor of Pathology, Bangladesh Institute of Child Health, Dhaka Shishu Hospital, Dhaka, Bangladesh.

*For correspondence

\section{References}

1. Chan TK. Erythrocyte glucose-6-phosphate dehydrogenase deficiency: The bulletin of the 20: $34-44$.

2. Chan TK. Glucose-6-phosphate dehydrogenase (G6PD) deficiency: A Review. HK $J$ Paediatr (New Series) 1996; 1: 23-30.

3. Beutler E. G6PD deficiency. Blood . 1994; 84(11): 3616-3636.

4. Kaplan M, Hammerman C. Glucose-6-phosphate dehydrogenase deficiency: A Worldwide Potential Cause of Severe Neonatal Hyperbilirubinemia. Pediatrics in Review Neo Reviews. 2000; 1: 32-39.

J Bangladesh Soc Physiol. 2009 Dec;4(2): 71-76 Hong kong Chinese Medical Association. 1968; 
5. Ardhakani SB, Nikkhah A, Sedaghat M. The association between G6PD deficiency and total serum bilirubin level in icteric neonates. Acta Medica Iranica. 2007; 45(3): 233-235.

6. Atay E, Bozaykut A, Ipek IO, Glucose-6phosphate dehydrogenase deficiency in neonatal indirect hyperbilirubinemia. J Trop pediatr. 2006; 52(1): 56-58.

7. Al-Omran A, Al-Ghazal F, Gupta S, Jhon TB. Glucose-6-phosphate dehydrogenase deficiency and neonatal jaundice in Al- Hofuf area. Ann Trop Paediatr. 1998; 7(2): 98-140.

8. Sultana N, Begum N, Begum S, Ferdousi S, Ali T. Efeects of vitamin E supplementation on some aspect of haematological variable in patient of haemolytic anaemic patient with Glucose-6Phosphate Dehydrogenase (G6PD) deficiency. Bangladesh Journal of Physiology \& Pharmacology. 2006; 22(1/2): 12-17.

9. Abolghashemi H, Mehrani H, Amid A. An update on the prevalence of glucose-6-Phosphate dehydrogenase deficiency and neonatal jaundice in Tehran neonates. Clin Biochem. 2004; 37(3): 241-4.
10. Smith JC. Disorders of red cell metabolism. In: Hoffbrand AV, Oatovsky D, Tuddenham ED. Posgraduate hematology. Oxford: Blackwell publishing Ltd; 2005.

11. Kaplan M, Hammerman C. Glucose-6-phosphate dehydrogenase deficient Neonates: A Potential Cause for concern in North America. Pediatrics. 2000; 106(6): 1478-1479.

12. Mohanty D, Mukherjee MB, Colah RB. Glucose-6phosphate dehydrogenase deficiency in India. Indian J Pediatr. 2004; 71(6): 525-529.

13. Salamatu J, Rostenberghe HV, Yusoff MN, Ghazali S, Ismail NZN, Matsuo M, Wahab AN, Nishio H. in glucose-6-phosphate dehydrogenase-deficient babies. Pediatr Int. 2005; 47: 258-261.

14. Kaplan M, Hammerman C. Severe neonatal hyperbilirubinemia: a potential complication of glucose-6-phosphate dehydrogenase deficiency. Clin Perinatol. 1998; 25: 575-590.

15. Weng YH, Chou YH, Lien RI. Hyperbilirubinemia in healthy neonates with glucose-6-phosphate dehydrogenase deficiency. Early Hum Dev. 2003; 71(2): 129-36. 